\title{
FUZZY MODELING OF THE EFFECTS OF DIFFERENT IRRIGATION DEPTH IN RADISH CROP. PART II: BIOMETRIC VARIABLES ANALYSIS
}

\author{
Ana C. M. R. Boso1, Camila P. Cremasco², Fernando F. Putti², Luís R. A. Gabriel Filho* \\ $2^{2 *}$ Corresponding author. São Paulo State University (UNESP), School of Sciences and Engineering/ Tupã - SP, Brasil. \\ E-mail: gabriel.filho@unesp.br | ORCID ID: http://orcid.org/0000-0002-7269-2806
}

\section{KEYWORDS}

biometric variables, fuzzy logic, irrigation depth, polynomial regression, neural network.

\begin{abstract}
In order to estimate the response of biometric variables in different irrigation depths in radish crop, as well as their relations in the development of the crop, a fuzzy mathematical analysis was carried out from irrigation with depths of different percentages of the crop evapotranspiration (ETc), using Gaussian pertinence functions for the input variable and triangular for the biometric output variables. Validations were performed using neural network models, smoothing splines and polynomial regression. The relation among the biometric variables was measured applying the Pearson correlation coefficient. The results showed that the fuzzy modeling presented superiority in the crop development estimate over the quadratic polynomial regression model, neural network and smoothing splines, because it achieved an average reduction of errors among the biometric variables, of $7.8 \% 94.6 \%$ and $9.2 \%$ for the RMSE in the respective models, as well as a better adjustment of the data with average $\mathrm{R}^{2}$ of the variables. The modeling with neural network showed inadequate agronomic behavior in data representation. Regarding biometric variables, the length and diameter of the tuberous root are inversely correlated, and the fresh phytomass of the tuberous root is correlated only with the fresh phytomass of the root.
\end{abstract}

\section{INTRODUCTION}

Radish (Raphanus sativus) is a crop that has its biometric parameters highly influenced by external factors. It belongs to the Brassicaceae family and is composed of tuberous roots below ground, and stem and leaves above it (Embrapa, 2012). The tuberous roots are divided into edible parts (where energy is stored) and fixing parts (where it fixes itself to the substrate, nutrients are absorbed, and water and mineral salts are conducted). The edible part can be found in several shapes, from elliptical to elongated or round forms, with diameters ranging between 2 and 5 centimeters. It can also be white, purple, red, or black colored, while its pulp is white (Dantas et al., 2015).

From studies of Filgueira (2007), the radish poor quality and productivity is related to the water stress and the soil temperature and can obtain spongy aspects of the root and cracks. In a study conducted by Bregonci et al. (2008), the diameter and length reduction of the roots in the two crop cycles was observed.

New structures for verifying information from field experiments allow the use of more advanced techniques. One option is the introduction of mathematical modeling, as it allows, in more advanced processes, to consolidate the results obtained experimentally (Bordin, 2016).

According to Gabriel Filho et al. (2015), the fuzzy logic enables such solidification in a more comprehensive way, because it is applied in vague concepts where it cannot allow the manipulation by traditional logic. By using sets, the fuzzy theory performs its concepts close to the human reasoning in inaccuracies sites (Cremasco et al., 2015, Olivindo et al., 2019).

The use of this tool can be employed in several agricultural areas, such as in studies involving the impacts generated by the irrigation depths in beet crop (Gabriel Filho et al., 2015), in analyzes involving the growth of lettuce crop irrigated with magnetically treated water (Putti,

\footnotetext{
${ }^{1}$ São Paulo State University (UNESP), School of Agriculture/ Botucatu - SP, Brasil.

${ }^{2}$ São Paulo State University (UNESP), School of Sciences and Engineering/ Tupã - SP, Brasil.
}

Area Editor: Adunias dos Santos Teixeira

Received in: 5-11-2020

Accepted in: 3-23-2021 
2015), effects on tomato crop by the use of saline water (Bordin, 2016), among other studies that need mathematical and computational methods.

Given the above, this study aimed to analyze the efficiency of fuzzy modeling in estimating biometric parameters of the development of radish plants under different irrigation depths, based on crop evapotranspiration, correlating the parameters among themselves.

\section{MATERIAL AND METHODS}

\section{Experiment description}

The experiment was carried out from September to November 2013, at the Department of Rural Engineering of the School of Agronomic Sciences of UNESP, Botucatu, Brazil $\left(22^{\circ} 51^{\prime} S, 48^{\circ} 26^{\prime} \mathrm{W}\right.$, and $786 \mathrm{~m}$ altitude. The local climate is defined by Köppen's classification as $C f a$ type, which stands for humid subtropical climate (Köppen \& Geiger, 1928).

Crop evapotranspiration was measured using a classA tank installed in the vicinity of the experimental area. The measurements were performed daily at 08:00 a.m., with an accumulated value of $114.2 \mathrm{~mm}$ throughout the cycle.

The experiment irrigation used two independent drip systems, with a main line, and secondary lines with drips separated among each other in $0.30 \mathrm{~m}$, with a pressure of $10 \mathrm{~m} . w . c$. and a flow of $1.47 \mathrm{~L} . \mathrm{h}^{-1}$. The system efficiency was of $95 \%$ and for calculation of the irrigation, time the following equation was used:

$$
T i=6000 \frac{K c \cdot K p \cdot E c a \cdot S l \cdot S g \cdot T R}{E i \cdot V g}
$$

Where:

$K p:$ the tank coefficient;

$K c$ : the crop coefficient;

$S l$ : the spacing between sides $(m)$;

$E i$ : the irrigation efficiency $(\%)$;

Eca: the evaporation of "Class A" tank (mm day"-1);

$S g$ : spacing among drips $(m)$,

$V g:$ the drips flow $\left(\mathrm{L} h^{-1}\right.$.

The total irrigation depth was stipulated according to the methodology proposed by Snyder (1992), where it is necessary to use the tank coefficient $(K p)$ defined by the following equation:

$K p=0.0482+0.024 \ln (B)-0.00376 V+0.0045 U R$

Where:

$B:$ the border of the vegetation area around the tank (m);

$V$ : the wind speed at 2 meters high $\left(\mathrm{m} . \mathrm{s}^{-1}\right)$;

$K p$ : the tank coefficient;

$U H$ : the average of relative humidity in percentage.
The values of the irrigation depths applied were 28.6, $57.1,85.7,114.2$ and 142.8 , for $25 \%, 50 \%, 75 \%, 100 \%$ and $125 \%$, respectively. As definition for this study, the variables related to the tuberous root are indicating the values regarding the commercialized part of the root of the radish crop.

For the cultivation of radish, sowing was carried out directly in the soil, with pruning on the fourteenth day after the sowing (DAS). The spacing adopted among the crops was of $25 \mathrm{~cm}$ by $5 \mathrm{~cm}$, with plots of 4 planting lines in an area of $3.6 \mathrm{~m}^{2}$ described by $1.2 \mathrm{~m}$ wide and $3 \mathrm{~m}$ in length.

To evaluate the development and productivity of the radish crop, biometric variables were analyzed: leaf number (LN), root length (RL), tuberous root diameter (TRD), tuberous root length (TRL), fresh root phytomass (FRP), fresh leaf phytomass (FLP), fresh tuberous root phytomass (FTRP), dry root phytomass (DRP), dry leaf phytomass (DLP), dry tuberous root phytomass (DTRP).

The experiment was conducted in an entirely randomized design (RD), with 5 irrigation depth, where each depth was evaluated with 5 repetitions. The radish crop used in the experiment was Maçarias - Radish No. 19, of Sakata company.

After the harvest, there was the separation of biometric variables to obtain the desired data. The leaves were separated and counted manually. The fresh leaf phytomass was measured with the help of a digital scale graduated at $0.001 \mathrm{~g}$ and then maintained in a greenhouse with temperature of $65^{\circ} \mathrm{C}$ for 72 hours, performing the dry matter weighing. For measuring the root length, diameter and the tuberous root length, a caliper was used, calibrated in millimeter $(\mathrm{mm})$.

\section{Fuzzy Modeling}

Fuzzy models were developed to estimate the biometric variables of radish development and production at harvest point (35 days after transplant). The models were designed according to an agronomic model presented and defined by Putti (2015), which is based on the following function: $\quad f: X \subset \mathbb{R} \rightarrow \mathbb{R}^{10} ; \quad$ wherein $\quad F(x)=$ $\left(f_{1}(x), f_{2}(x), f_{3}(x), f_{4}(x), f_{5}(x), f_{6}(x), f_{7}(x), f_{8}(x)\right.$, $f_{9}(x), f_{10}(x)$ ), in which $x$ is the irrigation depth (\% ETc), with $x \in X=[25,125]$ and $y=\left(y_{i}\right)$ representing the biometric variables to be assessed.

The fresh root phytomass (FRP) variable was analyzed by several fuzzy models, with details of all possible methodological procedures in Boso et al. (2021).

Figure 1 shows the Fuzzy Rule Based System (SBRF) for radish crop, which is composed of five input variables, namely: Irrigation depths (\%), indicated as $\mathrm{Li}$, wherein $i=1,2,3,4,5$; ten output variables; and a set of five rules for the development of the system. This definition was materialized as the experiment was performed. The irrigation depths were estimated by ETc levels, increasing by $25 \%$ from one to another. Biometric variables of crop yield were used as output variables. 


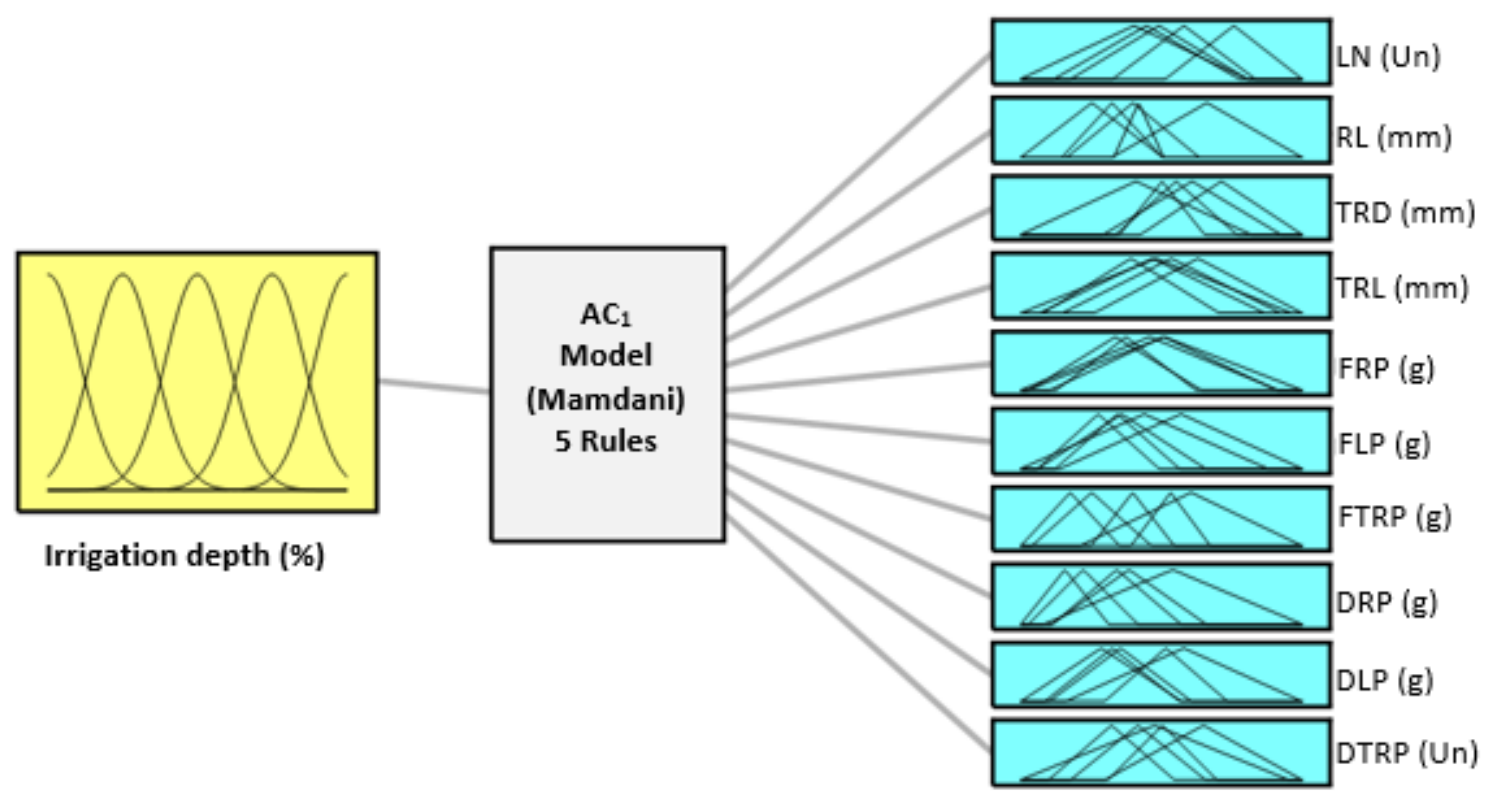

FIGURE 1. Fuzzy rule-based system for estimating radish crop yield, with Gaussian membership functions for the input variable (irrigation depth in \% of ETc) and triangular membership functions for the output biometric variables and 5 rules. Output variables: leaf number (LN), root length (RL), tuberous root diameter (TRD), tuberous root length (TRL), fresh root phytomass (FRP), fresh leaf phytomass (FLP), fresh tuberous root phytomass (FTRP), dry root phytomass (DRP), dry leaf phytomass (DLP), dry tuberous root phytomass (DTRP).

Figure 2 shows the Gaussian pertinence functions adopted for the fuzzy sets of the input variable "Irrigation Depth", which points with pertinence degree equals 1 represent the adopted depths, namely 25\%, 50\%, 75\%, 100\% and 125\% of the ETc.

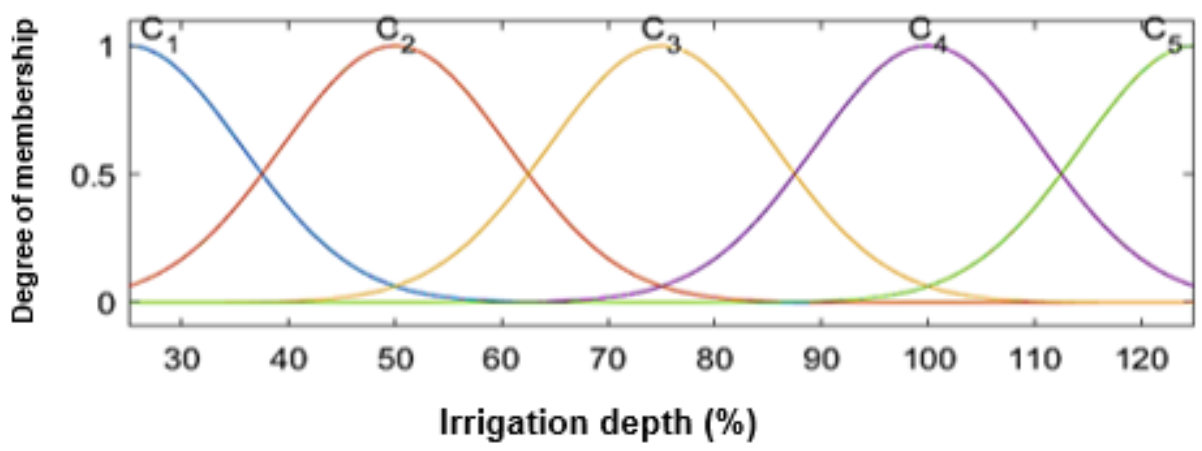

FIGURE 2. Gaussian pertinence functions for the input variables (irrigation depth), of the FRBS, related to the fuzzy sets $C_{1}, C_{2}, C_{3}, C_{4}$ and $C_{5}$, concerning the irrigation depths $25 \%, 50 \%, 75 \%, 100 \%$ and $125 \%$ of the ETc, respectively, with pertinence degree points varying between 0 and 1 .

The rule base was developed from the argument: "If Depths is $C_{i}$ then the output variable is $C_{k_{i}}, i=1,2,3,4,5$ " where the input variable is the antecedent and the output variable is the consequent. Five rules were created with the input (water dephts) and output variables the biometric variables (LN, RL, TRD, TRL, FRP, FLP, FTRP, DRP, DLP, DTRP).
The fuzzy rules construction was performed with the combinations among the mentioned variables, according to the pertinence degree that are associated to the input fuzzy sets $\left(C_{i}\right)$, and to the output fuzzy set $\left(C_{k_{i}}\right)$. Table 1 describes the combination of the input and output variables for the formation of the FRBS rule base. 
TABLE 1. FRBS rules base, for radish culture, in the estimate of the biometric variables in the harvest point, with 5 input fuzzy sets, 5 output fuzzy sets and 5 rules. Output sets: LN (leaf number); RL (root length); TRD (tuberous root diameter); TRL (tuberous root length); FRP (fresh root phytomass); FLP (fresh leaf phytomass); FTRP (fresh tuberous root phytomass); DRP (dry root phytomass; DLP (dry leaf phytomass); DTRP (dry tuberous root phytomass).

\begin{tabular}{|c|c|c|c|c|c|c|c|c|c|c|c|}
\hline \multirow{2}{*}{ Rules } & \multirow{2}{*}{ Input Sets } & \multicolumn{10}{|c|}{ Output Sets } \\
\hline & & $\mathrm{LN}$ & LR & TRD & TRL & FRP & FLP & FTRP & DRP & DLP & DTRP \\
\hline 1 & 1 & 5 & 4 & 2 & 4 & 5 & 4 & 3 & 4 & 5 & 4 \\
\hline 2 & 2 & 4 & 3 & 5 & 3 & 3 & 3 & 1 & 5 & 4 & 3 \\
\hline 3 & 3 & 3 & 5 & 4 & 1 & 4 & 5 & 4 & 3 & 3 & 5 \\
\hline 4 & 4 & 2 & 2 & 3 & 2 & 2 & 1 & 5 & 2 & 2 & 2 \\
\hline 5 & 5 & 1 & 1 & 1 & 5 & 1 & 2 & 2 & 1 & 1 & 1 \\
\hline
\end{tabular}

The construction and development of the fuzzy modeling, was initially analytical and subsequently structuring it mathematically with the aid of electronic spreadsheets (Excel software) and by the Fuzzy Logic Toolbox, present in Matlab® software. Similar systems can be found in Cremasco et al. (2010), Cremasco et al. (2015) Gabriel Filho et al. (2011, 2015, 2016), Pereira et al. (2008), Putti et al. (2014, 2017a, 2017b), Viais Neto et al. (2019a, 2019b), Martínez et al. (2020) and Góes et al. (2021).

\section{Model validation}

The efficiency of fuzzy models was analyzed by a polynomial regression of second degree. According to Sousa \& Alves (2016), regression analyses aim to predict possible relationships between dependent and independent variables in experimental data by mathematical models developed.

In order to realize and emphasize the efficiency of fuzzy modeling, it has also developed the smoothing spline modeling and neural network. According to Helwig (2017) splines is a set of flexible functions capable of smoothly modeling data. The analyzed data are called nodes, where these are in the spline interval. For each pair of nodes, the spline function assumed a polynomial of $n$ degree. The Smoothing Spline is defined for the parameter $p$ and weight $\mathrm{W}_{\mathrm{i}}$. The non-definition of weights presupposes 1 for all analyzed data and the $p$ value is defined between values 0 and 1 . The Smoothing Spline is defined by the minimizer (Boor, 2001):

$$
p \sum_{i} W_{i}\left(Y_{i}-f\left(x_{i}\right)\right)^{2}+(1-p) \int\left(\frac{D^{2} f}{D x^{2}}\right)^{2} D x
$$

For Teramoto et al. (2020), neural networks are made up of neurons capable of processing information efficiently. Using a data set and a training program, the algorithm allows estimating values closer to reality. For the data of the present study, 10 hidden neurons and the Levenberg-Marquardt algorithm were used. This algorithm is based on the least squares method, seeking to find the most appropriate adjustment for a given set of data, minimizing residues between the real data and the adjustment curve. Its resolution is given by the following equation (França et al., 2009):

$$
\left(J^{T}\left(x_{k}\right) J\left(x_{k}\right)+\lambda_{k} I\right) d_{k}=-J^{T}\left(x_{k}\right) R\left(x_{k}\right)
$$

Where:
$J$ is the Jacobian matrix;

$I$ is the identity matrix, and

$\lambda_{\mathrm{k}}$ is a determinable parameter.

From the generated models, we sought to measure their efficiency using the coefficient of determination $\left(\mathrm{R}^{2}\right)$ and the root mean square error (RMSE). The values of the deviation from the root mean square error (RMSE) indicate the uncertainty of the model according to the size of the error generated. The smaller the error presented, the better the model is adjusted (Santos et al., 2014; MeskiniVishkaee \& Davatgar, 2018). The determination coefficient $\left(\mathrm{R}^{2}\right)$ consists of validating the quality of the model in representing real data, in a range between 0 and 1, indicating as a percentage (Grácio \& Oliveira, 2015).

As a way to evaluate the influence of a variable in the development of another biometric variable of the studied crop, the correlation coefficient (r) was used, which indicates the linear association degree among the two variables and its direction measure. This association is expressed by a correlation coefficient, in a numerical way, by clouds of dots in a dispersion diagram (Martins \& Rodrigues, 2014).

The correlation coefficient has values understood between -1 and 1 , where the negative demonstrates that the variables are inverse, and the positive value demonstrates that the variables are direct. The higher the coefficient, the higher will be the association degree of the analyzed variables (Lordelo et al., 2018)

The yield estimation data for radish crop generated by the fuzzy model and by polynomial regression were statistically assessed by the Minitab software.

\section{RESULTS AND DISCUSSION}

Based on data of biometric parameters of radish yield, fuzzy models were employed by Gaussian pertinence functions for input variables (irrigation depths, in \%ETc) and triangular functions for output values (biometric variables).

Gaussian pertinence functions were chosen for Input variables because they produce smoother curves and better phenomenon presentation, from an agricultural point of view. However, by allowing function points to coincide with data averages and better results with fewer errors, a triangular pertinence function was used for output variables. Figure 3 shows triangular pertinence functions of the output variables, and Table 2 their delimiters. 

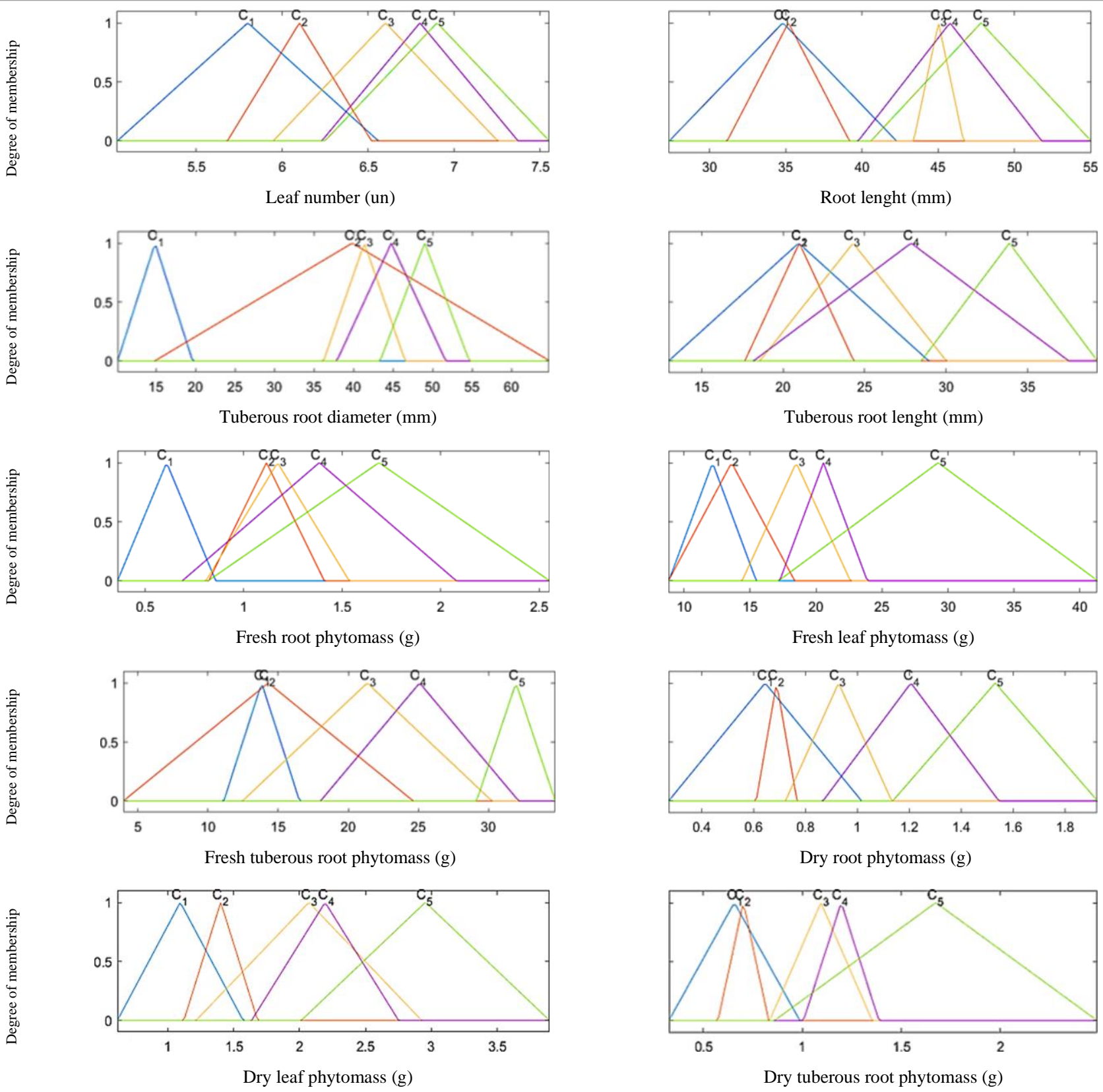

FIGURE 3. Triangular pertinence functions of the fuzzy sets $C_{1}, C_{2}, C_{3}, C_{4}$ and $C_{5}$ of the biometric (output) variables of the radish culture.

TABLE 2. Delimitators of the triangular pertinence functions of the fuzzy sets $C_{1}, C_{2}, C_{3}$, and $C_{5}$ of the biometric output variables, concerning the irrigation depths $25 \%, 50 \%, 75 \%, 100 \%$ and $125 \%$ of the ETc, respectively. Output sets: LN (leaf number); RL (root length); TRD (tuberous root diameter); TRL (tuberous root length); FRP (fresh root phytomass); FLP (fresh leaf phytomass); FTRP (fresh tuberous root phytomass); DRP (dry root phytomass; DLP (dry leaf phytomass); DTRP (dry tuberous root phytomass).

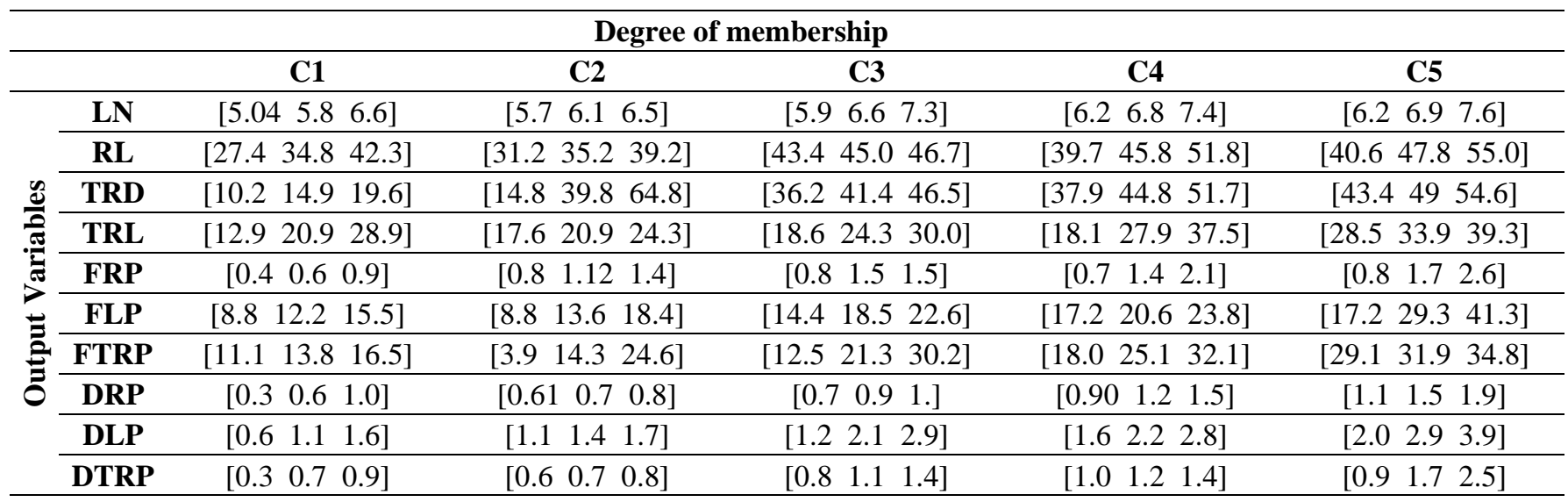


After defining the output pertinence functions, the efficiency of the models for each biometric variable was verified by statistical tests. Table 3 shows the statistical results obtained for the validation of the models.

TABLE 3. Validations for the biometric output variables of the radish culture, with information of the determination coefficient $\left(\mathrm{R}^{2}\right)$, root mean square error (RMSE) of the fuzzy model, smoothing splines, neural network and polynomial regression. Variables: RL (root length); LN (Leaves Number); DTR (Diameter of the tuberous root); TRL (tuberous root length); FRP (fresh root phytomass); FLP (fresh leaf phytomass); FTRP (fresh tuberous root phytomass); DRP (dry root phytomass); DLP (dry leaf phytomass); DTRP (dry tuberous root phytomass). All $\mathrm{R}^{2}$ values have $\mathrm{p}<1 \%$.

\begin{tabular}{|c|c|c|c|c|c|}
\hline Variable & Index & $\begin{array}{l}\text { Fuzzy } \\
\text { Model }\end{array}$ & $\begin{array}{c}\text { Polynomial } \\
\text { regression }\end{array}$ & $\begin{array}{c}\text { Smoothing } \\
\text { Splines }\end{array}$ & Neural Network \\
\hline \multirow{2}{*}{$\mathbf{L N}$} & $\mathbf{R}^{2}$ & 0.37 & 0.36 & 0.37 & 0.36 \\
\hline & RMSE & 0.56 & 0.56 & 0.62 & 0.34 \\
\hline \multirow{2}{*}{$\mathbf{R L}$} & $\mathbf{R}^{2}$ & 0.53 & 0.41 & 0.48 & 0.59 \\
\hline & RMSE & 5.20 & 5.81 & 5.90 & 26.05 \\
\hline \multirow{2}{*}{ TRD } & $\mathbf{R}^{2}$ & 0.54 & 0.52 & 0.53 & 0.49 \\
\hline & RMSE & 11.21 & 11.25 & 12.11 & 156.39 \\
\hline \multirow{2}{*}{ TRL } & $\mathbf{R}^{2}$ & 0.38 & 0.34 & 0.37 & 0.02 \\
\hline & RMSE & 6.14 & 6.34 & 6.67 & 448.10 \\
\hline \multirow{2}{*}{ FRP } & $\mathbf{R}^{2}$ & 0.34 & 0.27 & 0.32 & 0.33 \\
\hline & RMSE & 0.49 & 0.52 & 0.54 & 0.25 \\
\hline \multirow{2}{*}{ FLP } & $\mathbf{R}^{2}$ & 0.46 & 0.21 & 0.35 & 0.52 \\
\hline & RMSE & 6.37 & 7.46 & 7.29 & 33.92 \\
\hline \multirow{2}{*}{ FTRP } & $\mathbf{R}^{2}$ & 0.50 & 0.10 & 0.45 & 0.52 \\
\hline & RMSE & 6.89 & 8.81 & 7.49 & 42.04 \\
\hline \multirow{2}{*}{ DRP } & $\mathbf{R}^{2}$ & 0.59 & 0.43 & 0.55 & 0.59 \\
\hline & RMSE & 0.28 & 0.32 & 0.31 & 0.08 \\
\hline \multirow{2}{*}{ DLP } & $\mathbf{R}^{2}$ & 0.54 & 0.52 & 0.51 & 0.49 \\
\hline & RMSE & 0.60 & 0.61 & 0.66 & 0.41 \\
\hline \multirow{2}{*}{ DTRP } & $\mathbf{R}^{2}$ & 0.41 & 0.26 & 0.37 & 0.48 \\
\hline & RMSE & 0.42 & 0.46 & 0.46 & 0.15 \\
\hline \multirow{2}{*}{ Mean } & $\mathbf{R}^{2}$ & 0.47 & 0.34 & 0.43 & 0.44 \\
\hline & RMSE & 3.82 & 4.21 & 4.21 & 70.77 \\
\hline
\end{tabular}

According to the statistical analysis of the models, the fuzzy model stood out for all biometric parameters of radish yield when compared to the polynomial regression models. Fuzzy modeling promoted an average reduction of errors among biometric parameters by $7.83 \%$ for RMSE as well as better data fitting with average correlation coefficient of biometric parameters (25.9\%), thus showing its efficiency for estimating crop yield of radish.

Such fuzzy logic superiority over second-degree polynomial regression for MRSD was also observed by Silva et al., (2014), who analyzed wheat yield with nitrogen fertilization, as well as that by Putti (2015) when analyzing lettuce development when irrigated with magneticallytreated water.
Fuzzy models proved to be more suitable than smoothing splines and neural networks for data analysis. Smoothing splines had an average value of 4.2 of the RMSE error, while that of the fuzzy model was 3.8 for the analyzed parameters. Such a difference shows an average error reduction by $9.2 \%$, thus confirming the efficiency of fuzzy modeling. Neural networks had $\mathrm{R}^{2}$ values higher than the other models for some biometric parameters. However, the RMSE values (on average, 70.77) of the neural network model demonstrated its unsuitability for such analyses.

To represent a comparison of the model developed for each biometric parameter, Figure 4 graphically demonstrates a comparison between the fuzzy model and statistical model, highlighting the efficiency of each one. 

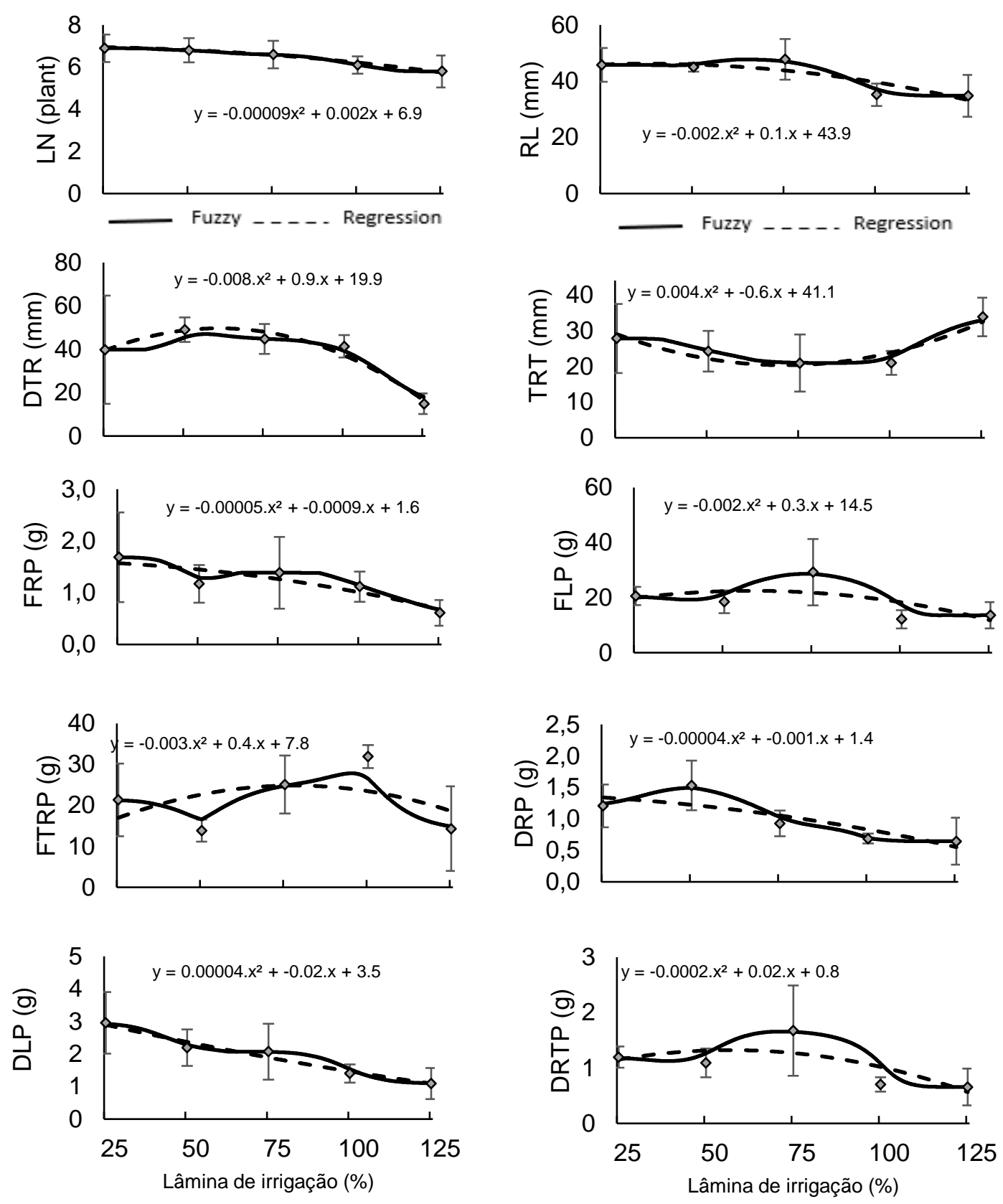

FIGURE 4. Comparison among the fuzzy and linear regression models of the biometric variables of the radish culture according to the irrigation depths. Variables: LN (leaf number); RL (root length); TRD (tuberous root diameter); TRL (tuberous root length); FRP (fresh root phytomass); FLP (fresh leaf phytomass); FTRP (fresh tuberous root phytomass); DRP (dry root phytomass; DLP (dry leaf phytomass); DTRP (dry tuberous root phytomass). In each variable, the quadratic regression equation is shown along the curve.

The response function for the number of leaves (LN) showed a difference between the proposed fuzzy model and the statistical model. However, when analyzing model validation, the fuzzy model presented an $\mathrm{R}^{2}$ of 0.37 for $\mathrm{LN}$, and 0.56 for RMSE, in contrast to the regression model that presented $\mathrm{R}^{2}$ of 0.36 for $\mathrm{LN}$, and 0.56 for RMSE.

Root length (RL) had higher estimates for irrigation depth of $75 \%$ ETc using the fuzzy model. For Wan \& Kang (2006), more developed root systems may be related to low water availability in the soil, as roots tend to grow more to meet their water needs. The same behavior could be seen for fresh root phytomass (FRP) and dry root phytomass (DRP).

Results of tuberous root diameter (TRD) for irrigation depths of 50 and $75 \%$ ETc were similar for both models analyzed. Likewise, Klar et al. (2015) analyzed TRD of radish and observed higher values for irrigation depths of 72 and $85 \%$ ETc. However, it reduced irrigation for irrigation depths of 25 and $125 \%$ ETc. This was also reported by Bregonci et al., (2008), who found TRD reductions when radish plants were submitted to water stress. Water deficit increases soil tension, increasing soil water retention and withdrawal by plants. On the other side, water excess decreases plant absorption of the oxygen in the soil, reducing development (Lacerda et al., 2017).

These radish development behaviors are physiological and biochemical consequences that affect biometric parameters. When subjected to stress, the first defense mechanism of plants is stomatal closure to prevent 
water loss (Hosseinzadeh et al., 2016). As a result, internal $\mathrm{CO}_{2}$ concentration increases, inhibiting Rubisco activity and hence photosynthesis (Rahbarian et al., 2011). Accordingly, it leads to biometric changes including increases in hypocotyls, internodes, petioles, sheaths, and leaf inclination angle; reductions in leaf area, branch length, and tillering; as well as early flowering (Zhang et al., 2019).

This can be seen also in the dry tuberous root phytomass (DTRP) and fresh tuberous root phytomass (FTRP), where they had low results with the irrigation depths of $25 \%$ and $125 \%$, and (1.2 and 21.3) and (0.7 and 14.3) respectively. The tuberous root length variable (TRL) achieved productivity in the depth of $125 \%(34 \mathrm{~mm})$, with approximation of its value in the depth of $25 \%,(28 \mathrm{~mm})$, when observed by the fuzzy modeling.

Analyzing the efficiency of the irrigation depths, by the fuzzy modeling in the biometric variables, it is verified that the depth corresponding to $75 \%$ of ETc presented significant production and development, in the radish crop, over the other irrigation depths used. The same can be seen by the polynomial regression model, where the irrigation depth in $75 \%$ of the ETc also demonstrates efficiency in the development of most of the biometric variables analyzed. This can be an option in the reduction of resources destined for irrigation for the radish crop, in the climate and local conditions of the experiment.

Regarding the neural network model, Figure 5 shows, from an agronomic point of view, the disadvantage of applying the model in data analysis. It is observed that among the irrigation depths of $100 \%$ and $125 \%$, the values obtained from the productivity of the dry phytomass variable of the tuberous root reached negative points, as well as peaks in the data representation curve, which is not consistent with phenomena related to the plant growth and with the opposite representation of fuzzy modeling, which demonstrated with efficiency and smoothness the curves in the data estimation.

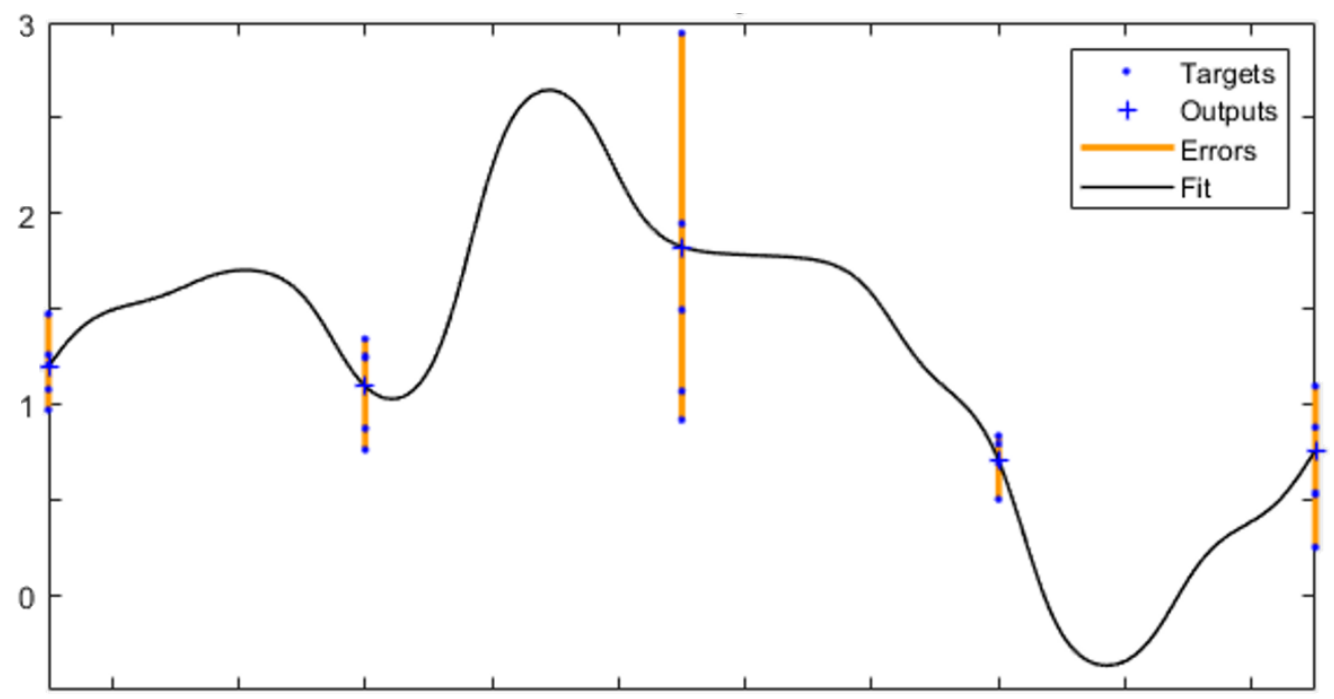

FIGURE 5. Graphical validation of the neural network model for the biometric variable Dry Tuberose Root Phytomass.

As a way to analyze the development relationship among the biometric variables, the Pearson correlation coefficient was calculated (Table 4). The Pearson ratio verifies the association degree between two variables, through the correlation coefficient and of the p-value.

TABLE 4. Correlations among the biometric output variables of the fuzzy model, for the radish culture, referring to the DAS 35. Variables with the symbol "* * demonstrated correlation at a 5\% significance level of the F test. Variables: RL (root length); LN (Leaves Number); DTR (Diameter of the tuberous root); TRL (tuberous root length); FRP (fresh root phytomass); FLP (fresh leaf phytomass); FTRP (fresh tuberous root phytomass); DRP (dry root phytomass); DLP (dry leaf phytomass); DTRP (dry tuberous root phytomass).

\begin{tabular}{cccccccccc}
\hline & LN & RL & TRD & TRL & FRP & FLP & FTRP & DRP & DLP \\
\hline RL & $0,52^{*}$ & & & & & & & & \\
TRD & $0,47^{*}$ & - & & & & & & \\
TRL & - & - & $-0,411^{*}$ & & & & & \\
FRP & $0,61^{*}$ & $0,58^{*}$ & - & - & & & & \\
FLP & $0,44^{*}$ & $0,81^{*}$ & - & - & $0,51^{*}$ & & & \\
FTRP & - & - & - & - & $0,42^{*}$ & - & & \\
DRP & $0,49^{*}$ & $0,53^{*}$ & $0,53^{*}$ & - & - & - & - & & \\
DLP & $0,73^{*}$ & $0,69^{*}$ & - & - & $0,89^{*}$ & $0,55^{*}$ & - & $0,49^{*}$ & \\
DTRP & $0,46^{*}$ & $0,84^{*}$ & $0,40^{*}$ & - & $0,58^{*}$ & $0,97^{*}$ & - & - & $0,62^{*}$ \\
\hline
\end{tabular}


It was verified that the variables, dry leaf phytomass (DLP) and fresh root phytomass (FRP) presented $r$ (correlation coefficient index) high and positive, with the leaf number variable (LN), with values 0.726 and 0.614 respectively. According to Putti (2015), this phenomenon occurs due to the high temperatures that are perceived in the site during the performance of an experiment, since high temperatures cause the plant to have greater growth in the initial phenological phases.

The root length variable (RL) presented high correlation with the dry tuberous root phytomass (DTRP) and fresh leaf phytomass (FLP) variables. According to ElDesuki et al. (2005), the root length productivity is related to the plant leaf number and the leaf area. This relation occurs due to a light interception, generating a greater production of photoassimilates.

Regarding the tuberous root diameter variable (TRD), a negative correlation was observed with the tuberous root length (TRL), that is, the variables are inverse. As the tuberous root diameter increases, the length decreases and vice versa. This is due to the high temperature in the cultivation period. According to Lima \& Oliveira (2018), the tuberous root growth is impaired by the high environment temperatures and by the excess of irrigation before the tuberous root development period. This promotes a fast TRD growth and a decrease of its length. The tuberous root growth coefficient with the other variables did not demonstrate significance at the level of $5 \%$.

The fresh leaf phytomass variable (FLP) reached a high correlation (0.970), with the dry tuberous root phytomass variable (DTRP). Hence, according to Lacerda et al. (2017), the relation between fresh leaf phytomass and the dry tuberous root phytomass is directed with the water availability. In his study, the author mentions that the crop productivity obtained better results when applied a depth of $100 \%$ and $125 \%$.

The similarity among the biometric variables can be related to the environment conditions, which allows better photosynthetic performance and higher quantity of photoassimilates (Santos et al., 2019; Silva et al., 2016)

\section{CONCLUSIONS}

According to the validation of the developed models (fuzzy and linear regression), the fuzzy model showed to be superior over the statistical model for all biometric parameters, with higher $\mathrm{R}^{2}$ values and lower error indexes (MRSP and MAE), thus demonstrating its efficiency in data estimation for the decision-making in setting irrigation timing. The quadratic polynomial regression model exhibited correlation coefficients $\left(R^{2}\right)$ of $p>0.05$, therefore, it is not a significant model for the analyzed data.

The same analysis also showed that the fuzzy modeling was also superior to the neural network and smoothing splines models, which had mean errors of RMSE for biometric parameters superior to the RMSE of the fuzzy modeling.

Neural network model cannot be used to represent yield data for radish crop since it showed curves with unsuitable behavior for agronomic representation.

The analyses showed that the fuzzy modeling was predominant in all developed models, with emphasis on its superiority over neural network modeling due to its more suitable $\mathrm{R}^{2}$ and RMSE for data validation, as well as its smooth graphical representation that is closer to the agronomic reality of crop development.

Based on the biometric parameters analyzed, radish crop can achieve high yields with an irrigation depth of $75 \%$ of the crop evapotranspiration, which can lead to great savings in relation to the final cost of production.

Correlation coefficients demonstrate that biometric parameters of radish have association with plant yield and photoassimilate productions.

\section{ACKNOWLEDGMENTS}

The authors would like to thank the National Council for Scientific and Technological Development (CNPq) for the research productivity scholarships awarded to the penultimate (Process 303923/2018-0) and to the last (Process 315228/2020-2) authors.

\section{REFERENCES}

Bregonci IS, Almeida GD, Brum VJ, Zini Júnior A, Reis EF (2008) Desenvolvimento do sistema radicular do rabanete em condição de estresse hídrico. Idesia (Arica) 26(1):33-38. DOI: http://doi.org/10.4067/S071834292008000100005

Boor C (2001) A practical guide to splines. New York: Springer, $346 \mathrm{p}$.

Bordin D (2016) Plataforma computacional fuzzy para avaliação nos estágios do tomateiro dos efeitos da irrigação e salinidade da água. Dissertação (Mestrado em Agronegócio e Desenvolvimento) - Universidade Estadual Paulista.

Boso ACMR, Cremasco CP, Putti FF, Gabriel Filho LRA (2021) Fuzzy modeling of the effects of different irrigation depths on the radish crop. Part I: Productivity analysis. Engenharia Agrícola 41(3).

Cremasco, CP, Gabriel Filho, LRA, Putti, FF, Ludwig, R, Silva Junior, JF (2015) Resposta da cultura do rabanete irrigado com água tratada magneticamente e convencional. In: XLIV Congresso Brasileiro de Engenharia Agrícola (CONBEA), São Pedro-SP. v. 54. p. 1-9

Cremasco CP, Gabriel Filho LRA, Cataneo A (2010) Metodologia de determinação de funções de pertinência de controladores fuzzy para a avaliação energética de empresas de avicultura de postura. Revista Energia na Agricultura 25 (1): 21-39 . DOI:

http://doi.org/10.17224/EnergAgric.2010v25n1p21-39

Dantas AEA, Souza TA, Alves TM, Souza TSL, Souto LS (2015) Produção de rabanete (Raphanus sativus L.) sob diferentes níveis e fontes de fertilizantes orgânicos. In: Congresso Técnico Científico da Engenharia e da Agronomia. Jaboticabal, Associação Brasileira de Engenharia Agrícola, 1-9.

EMBRAPA - Empresa Brasileira de Pesquisa Agropecuária (2012) Hortaliças em revista: importância nutricional das hortaliças. Embrapa Produção de informação, $16 \mathrm{p}$.

Filgueira FAR (2007) Novo manual de olericultura: agrotecnologia moderna na produção e comercialização de hortaliças, Viçosa, Universidade Federal de Viçosa, 3 ed. rev. 421p. 
França JA, Morais França MB, Koyama MH, Silva TP (2009) Uma implementação do algoritmo LevenbergMarquardt dividido para aplicações em visão computacional. Semina: Ciências Exatas e Tecnológicas 30(1): 51-62. DOI: http://doi.org/10.1590/0102-7786351010

Gabriel Filho LRA, Cremasco CP, Putti FF, Chacur MGM (2011) Application of fuzzy logic for the evaluation of livestock slaughtering. Engenharia Agrícola, 31(4):813825. DOI: http://doi.org/10.1590/S010069162011000400019

Gabriel Filho LRA, Pigatto GAS, Lourenzani AEBS (2015) Fuzzy rule-based system for evaluation of uncertainty in cassava chain. Engenharia Agrícola 35(2):350-367. DOI: http://doi.org/10.1590/1809-4430Eng.Agric.v35n2p350-367/2015

Gabriel Filho LRA, Putti FF, Cremasco CP, Bordin D, Chacur MGM, Gabriel LRA (2016) Software to assess beef cattle body mass through the fuzzy body mass index. Engenharia Agrícola 36(1): 179-193. DOI: http://doi.org/10.1590/1809-4430-Eng.Agric.v36n1p179$193 / 2016$

Góes BC, Goes RJ, Cremasco CP, Gabriel Filho LRA (2021) Fuzzy modeling of vegetable straw cover crop productivity at different nitrogen doses. Modeling Earth Systems and Environment, 7. DOI:

http://doi.org/10.1007/s40808-021-01125-4.

Grácio MCC, Oliveira EFT (2015) Indicadores de proximidades em análise de cocitação de autores: um estudo comparativo entre coeficiente de Correlação de Pearson e Cosseno de Salton. Informação e Sociedade: Estudos 25(2):105-116.

Helwig NE (2017) Regression with ordered predictors via ordinal smoothing splines. Frontiers in Applied Mathematics and Statistics 3: 15. DOI: http://doi.org/10.3389/fams.2017.00015

Hosseinzadeh SR, Amiri H, Ismaili A (2016) Effect of vermicompost fertilizer on photosynthetic characteristics of chickpea (Cicer arietinum L.) under drought stress. Photosynthetica 54(1):87-92. DOI: http://doi.org/10.1007/s11099-015-0162-x

Klar AE, Putti FF, Gabriel Filho LRA, Silva Júnior JF, Cremasco CP (2015) The effects of different irrigation depths on radish crops. Irriga 1(1):150-159. DOI: http://doi.org/10.15809/irriga.2015v1n1p150

Köppen W, Geiger R. Klimate der Erde. Gotha, Verlag Justus Perthes, 1928. Wall-map 150cmx200cm.

Lacerda VR, Gonçalves BG, Oliveira FG, Sousa YB, Castro IL (2017) Características morfológicas e produtivas do rabanete sob diferentes lâminas de irrigação. Revista Brasileira de Agricultura Irrigada 11(1):1127-1134. DOI: http://doi.org/10.7127/RBAI.V11N100513

Lordelo LMK, Hongyu K, Borja PC, Porsani MJ (2018) Análise fatorial por meio da matriz de correlação de Pearson e Policórica no campo das cisternas. Engineering and Science, 7(1):58-70.

http://doi.org/10.18607/ES201875266
Lima CEP, Oliveira VR (2018) Árvore do conhecimento: cebola. AGEITEC: Agência Embrapa de Informação tecnológica. Available:

http://www.agencia.cnptia.embrapa.br/gestor/cebola/arvor e/CONT000gn0iyu2a02wx5ok0liq1mq7mr143w.html. Accessed Maio 12, 2018.

Martínez MP, Cremasco CP, Gabriel Filho LRA, Braga Junior SS, Bednaski AV, Quevedo-Silva F, Correa CM, Silva D, Padgett RCML (2020) Fuzzy inference system to study the behavior of the green consumer facing the perception of greenwashing. Journal of Cleaner Production, 242: 116064. DOI:

http://doi.org/10.1016/j.jclepro.2019.03.060

Martins MEG, Rodrigues JF (2014) Coeficiente de correlação amostral. Revista de Ciência Elementar 2(2):3436. DOI: http://doi.org/10.24927/rce2014.042

Meskini-Vishkaee F, Davatgar N (2018) Evaluation of different predictor models for detailed soil particle-size distribution. Pedosphere 28(1): 157-164. DOI: https//doi.org/10.1016/S1002-0160(17)60422-3

Olivindo MS, Costa JV, Brito RX (2019) Sistema Fuzzy Como Ferramenta Auxiliadora na Predição de Malformações Fetais Causadas por Agrotóxicos. In: Anais da VII Escola Regional de Computação do Ceará, Maranhão e Piauí SBC, Anais...

Pereira DF, Bighi CA, Gabriel Filho LRA, Cremasco CPC (2008) Sistema fuzzy para estimativa do bem-estar de matrizes pesadas. Engenharia Agrícola 28(4):624-633. DOI: http://doi.org/10.1590/S0100-69162008000400002

Putti FF (2015) Análise dos indicadores biométricos e nutricionais da cultura da alface (Lactuca sativa $L$.) irrigada com água tratada magneticamente utilizando modelagem fuzzy. Tese Doutorado, Jaboticabal, Universidade Estadual Paulista.

Putti FF, Gabriel Filho LRA, Cremasco CP, Bonini Neto A, Bonini CSB, Reis AR (2017) A Fuzzy mathematical model to estimate the effects of global warming on the vitality of Laelia purpurata orchids. Mathematical Biosciences 288:124-129. DOI: http://doi.org/10.1016/j.mbs.2017.03.005

Putti FF, Gabriel Filho LRA, Silva AO, Ludwig R, Cremasco CP (2014) Fuzzy logic to evaluate vitality of catasetum fimbiratum species (Orchidacea). Revista Irriga 19(3):405-413. DOI:

http://doi.org/10.15809/irriga.2014v19n3p405

Putti FF, Kummer ACB, Grassi Filho H, Gabriel Filho LRA, Cremasco CP (2017) Fuzzy modeling on wheat productivity under different doses of sludge and sewage effluent. Engenharia Agrícola 37(6):1103-1115. DOI: http://doi.org/10.1590/1809-4430-eng.agric.v37n6p1103$1115 / 2017$ 
Rahbarian R, Khavari-Nejad R, Ganjeali A, Bagheri A, Najafi F (2011) Drought stress effects on photosynthesis, chlorophyll fluorescence and water relations in tolerant and susceptible chickpea (Cicer arietinum L.) genotypes. Acta biologica Cracoviensia. Series botânica 53:47-56. DOI: http://doi.org/10.2478/v10182-011-0007-2

Santos BDB, Silva PF, Matos RM, Borges VE, Dantas Neto J, Lima VLA (2019) Qualidade agronômica da cenoura sob níveis de salinidade da água de irrigação e adubação orgânica. Revista Ibero-Americana de Ciências Ambientais 10(2): 1-9. DOI:

http://doi.org/10.6008/CBPC2179-6858.2019.002.0001

Santos JD, Silva CD, Santos CD, Silva CDS, Melo E, Barros A (2014). Análise de crescimento e evapotranspiração da cultura do rabanete submetido a diferentes lâminas de água. Revista Verde de Agroecologia e Desenvolvimento Sustentável 9(1):151-156.

Silva AA, Silva IA, Teixeira Filho M, Buzetti S, Teixeira M (2014). Estimativa da produtividade de trigo em função da adubação nitrogenada utilizando modelagem neuro fuzzy. Revista Brasileira de Engenharia Agrícola e Ambiental 18(2):180-187. DOI: http://doi.org/10.1590/S1415-43662014000200008

Silva DFD, Pio R, Soares JDR, Nogueira PV, Peche, PM, Villa F (2016) The production of Physalis spp. seedlings grown under different-colored shade nets. Acta Scientiarum. Agronomy 38(2):257-263. DOI: http://doi.org/10.4025/actasciagron.v38i2.27893

Snyder RL (1992) Equation for evaporation pan to evapotranspiration conversions. Journal of Irrigation and Drainage Engineering 118(6):977-980. DOI: http://doi.org/10.1061/(ASCE)0733-9437(1992)118:6(977)

Sousa GC, Alves JMS (2016) A regressão linear de galton: atividades históricas para função afim e estatística básica usando planilhas eletrônicas. Conexões-Ciência e Tecnologia 9(4):26-36. DOI: http://doi.org/10.21439/conexoes.v9i4.936
Teramoto ÉT, Santos CMD, Escobedo JF, Pai AD, Silva SHMG (2020) Comparing different methods for estimating hourly solar ultraviolet radiation: Empirical Models, Artificial Neural Network and Support Vector Machine. Revista Brasileira de Meteorologia 35(1): 35-43. DOI: http://doi.org/10.1590/0102-7786351010

Viais Neto DS, Cremasco CP, Bordin D, Putti FF, Silva Junior JF, Gabriel Filho LRA (2019) Fuzzy modeling of the effects of irrigation and water salinity in harvest point of tomato crop. Part I: Description of the method. Engenharia Agrícola 39(3):294-304. DOI: http://doi.org/10.1590/18094430-eng.agric.v39n3p294-304/2019

Viais Neto DS, Cremasco CP, Bordin D, Putti FF, Silva Junior JF, Gabriel Filho LRA (2019) Fuzzy modeling of the effects of irrigation and water salinity in harvest point of tomato crop. Part II: Application and interpretation. Engenharia Agrícola 39(3):305-14. DOI: http://doi.org/10.1590/1809-4430-eng.agric.v39n3p305$314 / 2019$

Vieira JH, Silva FD (2017) Resposta da cultura da beterraba a distintos níveis de quantidade e qualidade da água de irrigação em Alagoas. In: Congresso Nacional de Irrigação e Drenagem, UFS - São Cristóvão/SE 996-1001. Available: http://www.abid.org.br/cd-xxvconird/PDF/168.pdf. Accessed Ago 9, 2019

Wan S, Kang Y (2006) Effect of drip irrigation frequency on radish (Raphanus sativus $L$.) growth and water use. Irrigation Science 24:161-174. DOI: http://doi.org/10.1007/s00271-005-0005-9

Zhang N, Westreenen AV, Anten NP, Evers JB, Marcelis LF (2019) Disentangling the effects of photosynthetically active radiation and red to far-red ratio on plant photosynthesis under canopy shading. A simulation study using a functional-structural plant model. Annals of Botany 1-12. DOI: http://doi.org/10.1093/aob/mcz197 